Case Report

\title{
Tongue Necrosis Secondary to Giant Cell Arteritis: A Case Report and Literature Review
}

\author{
Rafael Alex Barbosa de Siqueira Sobrinho, ${ }^{1}$ Karolina Cayres Alvino de Lima, ${ }^{1}$ \\ Helena Carvalho Moura, ${ }^{2}$ Mônica Modesto Araújo, ${ }^{3}$ \\ Christyanne Maria Rodrigues Barreto de Assis, ${ }^{1}$ and Pedro Alves da Cruz Gouveia ${ }^{1}$ \\ ${ }^{1}$ Internal Medicine Service, Federal University of Pernambuco, Recife, PE, Brazil \\ ${ }^{2}$ School of Medicine, Federal University of Pernambuco, Recife, PE, Brazil \\ ${ }^{3}$ Pathology Service, Federal University of Pernambuco, Recife, PE, Brazil \\ Correspondence should be addressed to Pedro Alves da Cruz Gouveia; pedroalves@doctor.com
}

Received 16 November 2016; Accepted 14 March 2017; Published 23 March 2017

Academic Editor: Bruno Megarbane

Copyright (C) 2017 Rafael Alex Barbosa de Siqueira Sobrinho et al. This is an open access article distributed under the Creative Commons Attribution License, which permits unrestricted use, distribution, and reproduction in any medium, provided the original work is properly cited.

\begin{abstract}
Giant cell arteritis is a form of vasculitis involving the medium- and large-sized arteries that chiefly affects older people. Clinical findings are headache, jaw claudication, fever, pain, and thickening of the temporal artery. The most feared complication is visual loss due to impairment of the ophthalmic artery and posterior ciliary arteries. This a case report of an 85-year-old male presenting with headache and jaw pain, who was admitted with tongue necrosis as an initial manifestation of giant cell arteritis. The necrotic area detached spontaneously after two weeks of therapy with corticosteroids and methotrexate. Reviewing the literature, our patient presented with clinical symptoms consistent with most reports, except for the fact of being male. Although unusual as an initial manifestation, tongue necrosis is an important alert for diagnosing giant cell arteritis. Early diagnosis and treatment of this atypical manifestation may reduce morbidity.
\end{abstract}

\section{Introduction}

Giant cell arteritis (GCA) is a form of vasculitis involving medium- and large-sized arteries, which mainly affects the extracranial branches of the internal and external carotid arteries, particularly the temporal artery. GCA occurs predominantly in females in a ratio of 1.4 to 3 women for every man and exclusively in patients aged 50 years and over $[1,2]$. Common symptoms include headache; visual symptoms such as diplopia, amaurosis fugax, and vision loss; and masticatory muscle changes such as jaw claudication $[3,4]$.

Early diagnosis is vital in order to avoid complications, such as symptoms of ischemia [5, 6]. In some patients, however, unusual symptoms, such as lingual necrosis may appear as an initial manifestation, thus hindering diagnosis [7-9]. In this report, we present a case of GCA in an elderly male with early tongue necrosis.

\section{Case Presentation}

A male, aged 85 years, arrived in the emergency department having suffered from frontotemporal headache associated with jaw pain over a period of 30 days. He reported that the pain had worsened during the last seven days and that pain had also developed on the floor of the mouth and chin. He also presented with a medical history of hypertension, cataracts, and osteoporosis. On admission, neurological examination and neuroimaging indicated no significant changes.

On the second day of hospitalization, the patient presented with increased lingual volume associated with intense pain and difficulty in eating. Inspection of the tongue revealed diffuse edema, whitish plaques, and a small aphthous ulcer. Treatment was initiated for oral candidiasis with fluconazole, and later Candida dubliniensis was isolated from a lingual 


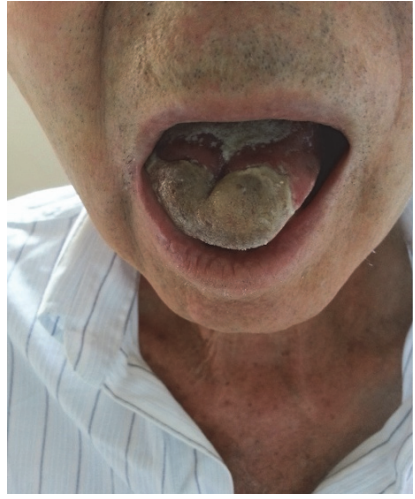

(a)



(b)

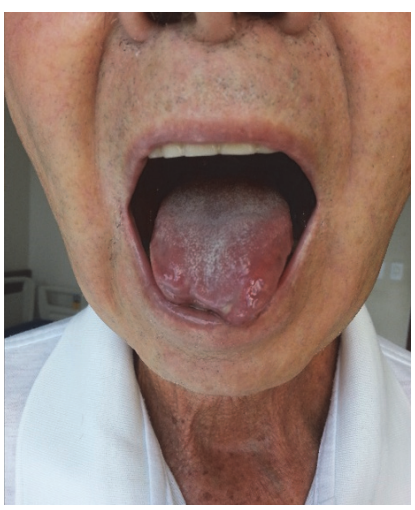

(c)

Figure 1: Clinical appearance of the tongue. (a) Tongue infarction at second day. (b) Initial auto-amputation of necrotic tongue at fifth day. (c) Tongue at 20th day presenting full epithelization.

swab. Within 24 hours, the lesion had changed colour, becoming greyish in a bilateral well-defined area, suggesting an ischemic lesion (Figure 1). Temporal pulses were absent and transient bilateral amaurosis appeared, thus confirming the presumptive diagnosis of GCA. Prednisone therapy was initiated with $1 \mathrm{mg} / \mathrm{kg} /$ day.

Initial laboratory investigation indicated a complete blood count with mild leukocytosis, neutrophilia, thrombocytosis, and anemia (hemoglobin $11.7 \mathrm{~g} / \mathrm{dL}$, hematocrit $36 \%, 14,290$ leukocytes $/ \mathrm{mm}^{3}$ with $89 \%$ neutrophils, and 481,000 platelets $/ \mathrm{mm}^{3}$ ). The erythrocyte sedimentation rate (ESR) of $120 \mathrm{~mm} / \mathrm{h}$ and a C-reactive protein (CRP) of $17.2 \mathrm{mg} / \mathrm{dl}$ were consistent with an acute inflammatory process. Other laboratory tests were normal.

Doppler ultrasonography demonstrated that the temporal arteries were tortuous and presented diffuse intimal thickening with edema of the surrounding tissue (halo sign), and stenosis of around $75 \%$ of the light from the right temporal artery. A diagnosis of GCA was confirmed with a biopsy from the right temporal artery, which presented partial necrosis of the arterial wall with inflammatory infiltration mainly of mononuclear type (lymphocytes, histiocytes, plasma cells, and multinucleated giant cells) permeating the internal elastic lamina; calcification foci; and total lumen stenosis (Figure 2).

After glucocorticoid therapy was initiated, the patient presented a significant clinical and laboratory response. The area of the tongue that displayed the delimited necrotic lesion detached spontaneously within fourteen days and there was no progression of the ischemic region (Figure 1). After two weeks was initiated methotrexate $10 \mathrm{mg} /$ week, and the patient was discharged clinically stable, and during his outpatient visits no new events or recurrences of GCA were reported. The prednisone dose was initially reduced by $10 \mathrm{mg}$ every month until $20 \mathrm{mg} /$ day and then reduced slowly. After twelve months, with evidence of normal inflammatory activity, the glucocorticoid was completely withdrawn.

\section{Discussion}

The manifestations of GCA include headache in $90 \%$ of cases, polymyalgia rheumatica (34\%), jaw claudication

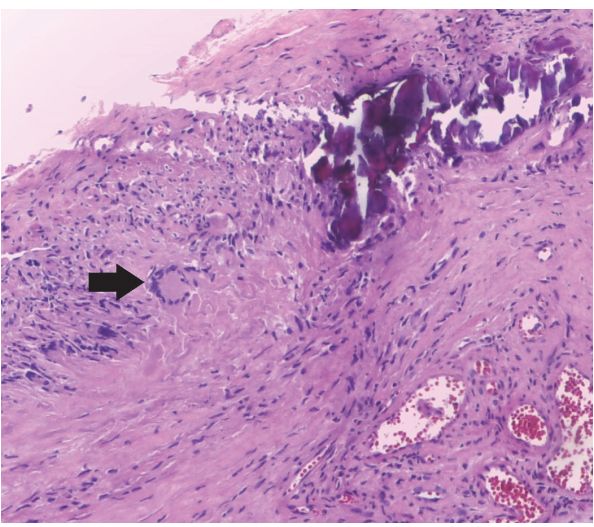

FIGURE 2: Histological appearance of temporal artery biopsy, showing places of dystrophic calcinosis, extensive transmural infiltrate of lymphocytes, and histiocytes with giant cell (black arrow) placed adjacent to internal elastic lamina (haematoxylin and eosin, original magnification $\times 100$ ).

(50\%), amaurosis fugax, and blurred vision (40\%). Other findings include fever, increased erythrocyte sedimentation rate, leukocytosis, and abnormalities in the temporal artery $[4,6,10]$. Ocular symptoms should also be highlighted due to the risk of vision loss, for which treatment should be instituted promptly [2].

Lingual manifestations such as edema, pallor, pain, and intermittent claudication occur in up to $25 \%$ of cases and can be associated with a greater risk of ischemic complications. However, tongue necrosis is rare, given the rich blood supply to this tissue [1,11]. GCA with tongue and/or scalp necrosis tends to occur more in older people and develops with more visual symptoms [7]. Tongue necrosis is an unfavorable prognostic sign since it is associated with increased mortality, although not part of the classification criteria [7].

While GCA is the main cause of tongue necrosis, other less common etiologies should be excluded, like carcinoma, embolism, drug use, radiation, syphilis, tuberculosis, chemotherapy, among others $[1,8,12]$. Other causes were not present in this case report; thus treatment was initiated for 
TABLE 1: Literature review of giant cell arteritis with tongue necrosis.

\begin{tabular}{|c|c|c|c|c|c|}
\hline Author & Ref. & Age/Sex & ESR & Associated symptoms & Treatment \\
\hline Mumoli (2015) & {$[16]$} & $77 / \mathrm{F}$ & No & $\begin{array}{l}\text { Pain in the scapular cingulum, pain and swelling in } \\
\text { both the wrists, transient reduction in visual acuity } \\
\text { and headache }\end{array}$ & Steroids \\
\hline Zaragoza (2015) & {$[8]$} & $68 / \mathrm{F}$ & 55 & Moderate headache and swelling of the neck & High dose corticosteroids at $1 \mathrm{mg} / \mathrm{kg}$ \\
\hline $\begin{array}{l}\text { Lobato-Berezo } \\
(2014)\end{array}$ & {$[17]$} & $74 / \mathrm{F}$ & No & $\begin{array}{c}\text { Fatigue, anorexia, jaw pain and headache, with ptosis } \\
\text { and blurred vision in her left eye }\end{array}$ & $\begin{array}{l}\text { Pulse with methylprednisolone and oral } \\
\text { prednisone } 1 \mathrm{mg} / \mathrm{kg} / \text { day }\end{array}$ \\
\hline Kumar (2013) & {$[18]$} & $74 / \mathrm{M}$ & 132 & $\begin{array}{c}\text { High-grade fever, bilateral temporoparietal } \\
\text { headache, jaw claudication and diminished vision in } \\
\text { both eyes }\end{array}$ & Oral prednisolone $1 \mathrm{mg} / \mathrm{kg} /$ day \\
\hline Grant (2013) & {$[5]$} & $79 / \mathrm{F}$ & 68 & $\begin{array}{l}\text { Sudden complete visual loss in the left eye and } \\
\text { generalized ongoing headache }\end{array}$ & $\begin{array}{l}\text { Oral prednisolone } 60 \mathrm{mg} / \text { day and pulse with } \\
500 \mathrm{mg} \text { methylprednisolone for three days }\end{array}$ \\
\hline $\begin{array}{l}\text { Kumarasinghe } \\
\text { (2012) }\end{array}$ & {$[19]$} & $74 / \mathrm{F}$ & 103 & $\begin{array}{l}\text { Vague history of mild headaches and jaw pain on } \\
\text { chewing }\end{array}$ & Oral prednisolone $40 \mathrm{mg} /$ day \\
\hline $\begin{array}{l}\text { Husein-ElAhmed } \\
\text { (2012) }\end{array}$ & {$[20]$} & $76 / \mathrm{F}$ & 87 & Generalised weakness & Oral prednisone \\
\hline Zadik (2011) & {$[1]$} & $78 / \mathrm{F}$ & 69 & $\begin{array}{l}\text { Pain of the right head, neck, face, and shoulder, } \\
\text { fatigue, visual blurring and weight loss }\end{array}$ & Prednisone $60 \mathrm{mg} /$ day \\
\hline Jennings (2011) & {$[21]$} & $79 / \mathrm{F}$ & 75 & $\begin{array}{l}\text { Fatigue, bilateral occipital neck pain and jaw } \\
\text { claudication }\end{array}$ & Steroid treatment \\
\hline Olivera (2010) & {$[4]$} & $74 / \mathrm{F}$ & 83 & Headache, anorexia, weakness and jaw claudication & Oral methylprednisolone $1 \mathrm{mg} / \mathrm{kg}$ \\
\hline $\begin{array}{l}\text { Brodmann (2009) } \\
\text { Case } 1\end{array}$ & {$[7]$} & $81 / \mathrm{M}$ & 52 & Chronic fatigue & Glucocorticoid therapy \\
\hline $\begin{array}{l}\text { Brodmann (2009) } \\
\text { Case } 2\end{array}$ & {$[7]$} & $79 / \mathrm{F}$ & 70 & $\begin{array}{c}\text { Sudden visual loss at the right eye, temporal } \\
\text { headache and jaw claudication }\end{array}$ & High-dose steroid therapy \\
\hline $\begin{array}{l}\text { Zimmermann } \\
(2008)\end{array}$ & {$[22]$} & $81 / \mathrm{F}$ & 69 & $\begin{array}{l}\text { Bitemporal headache, jaw claudication and mild } \\
\text { limb-girdle symptoms }\end{array}$ & High-dose intravenous hydrocortisone \\
\hline Schurr (2008) & {$[10]$} & $66 / \mathrm{F}$ & 120 & Slow speech and a worsening dysphagia & $\begin{array}{l}\text { Intravenous prednisone } 500 \mathrm{mg} \text { for } 3 \text { days, } \\
\text { then reduced dose of } 100 \mathrm{mg}\end{array}$ \\
\hline Sainuddin (2008) & {$[9]$} & $88 / \mathrm{F}$ & 78 & Generalized weakness & Prednisone $40 \mathrm{mg} /$ day \\
\hline Kusanale (2008) & {$[23]$} & $86 / \mathrm{F}$ & 25 & No information & Steroids \\
\hline Ciantar (2008) & {$[12]$} & $74 / \mathrm{F}$ & 79 & Neck pain & $\begin{array}{l}\text { Methylprednisolone } 1 \mathrm{~g} \text { IV for } 3 \text { days, } \\
\text { prednisolone } 60 \mathrm{mg} / \text { day and methotrexate } \\
12.5 \mathrm{mg} \text { weekly }\end{array}$ \\
\hline $\begin{array}{l}\text { Goicochea (2007) } \\
\text { Case } 1\end{array}$ & {$[11]$} & $77 / \mathrm{F}$ & 40 & $\begin{array}{l}\text { Asthenia, fever, right temporal headache, and } \\
\text { hemifacial pain }\end{array}$ & $\begin{array}{l}\text { Methylprednisolone } 1 \mathrm{~g} \mathrm{IV} \\
\text { cyclophosphamide IV and prednisone } \\
80 \mathrm{mg} / \text { day }\end{array}$ \\
\hline $\begin{array}{l}\text { Goicochea (2007) } \\
\text { Case } 2\end{array}$ & {$[11]$} & $73 / \mathrm{F}$ & 42 & $\begin{array}{l}\text { Frontotemporal headache, arthralgias and lost vision } \\
\text { in right eye }\end{array}$ & $\begin{array}{l}\text { Methylprednisolone } 1 \mathrm{~g} \text { IV for } 3 \text { days and } \\
\text { prednisone } 80 \mathrm{mg} / \text { day }\end{array}$ \\
\hline $\begin{array}{l}\text { Goicochea (2007) } \\
\text { Case } 3\end{array}$ & {$[11]$} & $78 / \mathrm{F}$ & 125 & $\begin{array}{l}\text { Headache, left eye visual loss, diplopia, fever and } \\
\text { swelling }\end{array}$ & $\begin{array}{l}\text { Methylprednisolone } 500 \mathrm{mg} \text { IV for } 3 \text { days } \\
\text { and } 60 \mathrm{mg} / \text { day orally }\end{array}$ \\
\hline Lethert (2007) & {$[24]$} & $77 / \mathrm{F}$ & 68 & $\begin{array}{c}\text { Head, neck and jaw pain, fever, slurred speech and } \\
\text { difficulty chewing. }\end{array}$ & Corticosteroids \\
\hline Biebl (2004) & {$[6]$} & $79 / \mathrm{F}$ & 78 & $\begin{array}{l}\text { Visual reduction on the left eye, abdominal pain with } \\
\text { multiple segmental small bowel necrosis }\end{array}$ & $\begin{array}{l}\text { Prednisolone and azathioprine }(100 \mathrm{mg} / \text { day } \\
\text { each })\end{array}$ \\
\hline García (2003) & {$[25]$} & $83 / \mathrm{F}$ & 67 & Fever, limb-girdle symptoms, occasional headache & Corticosteroids and methotrexate \\
\hline Rockey (2002) & {$[2]$} & $71 / \mathrm{F}$ & 125 & $\begin{array}{c}\text { Headache, vasculitic rash in buttocks and ischemia } \\
\text { over the distal phalanx of thumb and fifth } \\
\text { metatarsals bilaterally }\end{array}$ & High-dose steroid therapy \\
\hline Hellmann (2002) & {$[3]$} & $79 / \mathrm{F}$ & 115 & Fatigue, cough, toothache and visual loss & $\begin{array}{l}\text { Methylprednisolone IV in high doses and } \\
\text { prednisone } 60 \mathrm{mg} / \text { day }\end{array}$ \\
\hline
\end{tabular}

Ref: reference; ESR: erythrocyte sedimentation rate; M: male; F: female. 
GCA, since the patient met four of the five criteria cited by the American College of Rheumatology: aged over 50 years, reduced temporal pulse, ESR greater than $50 \mathrm{~mm} / \mathrm{h}$, and a compatible biopsy $[5,8,9]$.

The use of corticosteroids remains the cornerstone of therapy for GCA $[3,10]$. The recommended dose is $1 \mathrm{mg} / \mathrm{kg} /$ day of prednisone for four to six weeks and, thereafter, tapering off begins aiming at a dose of $10 \mathrm{mg} /$ day [5]. Recurrences occur in $50 \%$ of patients and adverse effects are common [13]. In cases involving visual loss or amaurosis fugax (complicated GCA) intravenous methylprednisolone is indicated for three days before oral glucocorticosteroids. It is possible to try to withdraw corticosteroids after four weeks, paying close attention to clinical symptoms and to ESR and CRP levels [14]. For adjunctive therapy, methotrexate, azathioprine, cyclophosphamide, and anti-TNF-alpha agents may be used [13]. Methotrexate is the first choice as steroid sparing drug because it has proven effective in reducing the cumulative dose of and preventing recurrences $[13,14]$.

The intensity of the initial inflammatory response of GCA can be determined by five parameters: Platelets $>400,000 /$ $\mathrm{mm}^{3}$, temperature $>37.5^{\circ} \mathrm{C}$, leukocytes $>11,000 / \mathrm{mm}^{3}$, ESR $>100 \mathrm{~mm} / \mathrm{h}$, and hemoglobin $<11 \mathrm{~g} / \mathrm{dl}$. Patients who meet four or five of these criteria are considered at high risk for recurrence and dependence on corticosteroids [15]. In this case, we chose to initiate methotrexate, given the severity of the recorded criteria (leukocytosis, thrombocytosis, and elevated ESR) associated with tongue necrosis, which in itself presents the worst prognosis. Moreover, the patient presented with comorbidities such as osteoporosis and cataracts, which indicate the need for early use of corticosteroid sparing.

A literature review was conducted using PubMed for case reports either in English or in Spanish of patients presenting with tongue necrosis as a clinical manifestation of GCA. We identified 22 articles published between 2000 and 2015 [1-12, 16-25], which reported 25 cases (Table 1). We found that most patients with GCA-associated lingual necrosis were older females. The ratio was of twelve women for every man, with a mean age of 77 years and an ESR of $79 \mathrm{~mm} / \mathrm{h}$. By analyzing the pattern of necrosis, we observed that $80 \%$ of patients presented with local pain, $50 \%$ with tongue edema, and $28 \%$ progressed to ulceration. In relation to associated symptoms, only seven patients (29\%) did not present with headache as an initial manifestation. Ocular symptoms, such as blurred vision and sudden visual loss, occurred in $38 \%$. In this review, all patients were treated with high doses of corticosteroids and $28 \%$ received pulse therapy with methylprednisolone. The response to corticosteroids was, in the majority (76\%) satisfactory, with good healing and disease control. Only one patient progressed to the need for a new course of methylprednisolone [11]. A second drug was used (intravenous cyclophosphamide, methotrexate, and azathioprine) in four cases $[6,11,12,25]$.

For the above-mentioned reasons, our patient presented with clinical findings that were consistent with most reports, except for the fact of being male. Tongue necrosis should serve as a warning for GCA, although it is unusual as an initial manifestation. The physician should be aware of this atypical manifestation, especially since diagnosis and early treatment may change the natural course of the disease, thus reducing morbidity.

\section{Conflicts of Interest}

The authors declare that there are no conflicts of interest regarding the publication of this paper.

\section{Acknowledgments}

Authors thank the patient for sharing his story and Dr. Hely José Farias Neto (in memoriam) for initial patient care.

\section{References}

[1] Y. Zadik, M. Findler, A. Maly, H. Rushinek, and R. Czerninski, "A 78-year-old woman with bilateral tongue necrosis," Oral Surgery, Oral Medicine, Oral Pathology, Oral Radiology and Endodontology, vol. 111, no. 1, pp. 15-19, 2011.

[2] J. G. Rockey and R. Anand, "Tongue necrosis secondary to temporal arteritis: a case report and literature review," Oral Surgery, Oral Medicine, Oral Pathology, Oral Radiology, and Endodontology, vol. 94, no. 4, pp. 471-473, 2002.

[3] D. B. Hellmann, "Temporal arteritis: a cough, toothache, and tongue infarction," Journal of the American Medical Association, vol. 287, no. 22, pp. 2996-3000, 2002.

[4] S. Olivera, B. Amores, M. Torralba, and J. Pérez Calvo, "Paciente con complicación poco frecuente de arteritis de células gigantes," Anales del Sistema Sanitario de Navarra, vol. 33, no. 3, pp. 327-330, 2010.

[5] S. W. J. Grant, H. C. Underhill, and P. Atkin, "Giant cell arteritis affecting the tongue: a case report and review of the literature," Dental Update, vol. 40, no. 8, pp. 669-677, 2013.

[6] M. O. Biebl, B. Hugl, L. Posch et al., "Subtotal tongue necrosis in delayed diagnosed giant-cell arteritis: a case report," American Journal of Otolaryngology-Head and Neck Medicine and Surgery, vol. 25, no. 6, pp. 438-441, 2004.

[7] M. Brodmann, A. Dorr, F. Hafner, T. Gary, and E. Pilger, "Tongue necrosis as first symptom of giant cell arteritis (GCA)," Clinical Rheumatology, vol. 28, no. 1, pp. S47-S49, 2009.

[8] J. R. Zaragoza, N. Vernon, and G. Ghaffari, "Tongue necrosis as an initial manifestation of giant cell arteritis: case report and review of the literature," Case Reports in Rheumatology, vol. 2015, Article ID 901795, 4 pages, 2015.

[9] S. Sainuddin and N. R. Saeed, "Acute bilateral tongue necrosis-a case report," British Journal of Oral and Maxillofacial Surgery, vol. 46, no. 8, pp. 671-672, 2008.

[10] C. Schurr, A. Berthele, M. Burghartz, and J. Kiefer, "Spontaneous bilateral necrosis of the tongue: a manifestation of giant cell arteritis?" European Archives of Oto-Rhino-Laryngology, vol. 265, no. 8, pp. 993-998, 2008.

[11] M. Goicochea, J. Correale, L. Bonamico et al., "Tongue necrosis in temporal arteritis," Headache, vol. 47, no. 8, pp. 1213-1215, 2007.

[12] M. Ciantar and D. M. Adlam, "Glossodynia and necrosis of the tongue caused by giant cell arteritis," British Journal of Oral and Maxillofacial Surgery, vol. 46, no. 3, pp. 231-233, 2008.

[13] J. Choulerton and R. Luqmani, "Management of corticosteroid resistant giant cell arteritis," Acta Reumatológica Portuguesa, vol. 30, pp. 329-339, 2005. 
[14] B. Dasgupta, F. A. Borg, N. Hassan et al., "BSR and BHPR guidelines for the management of giant cell arteritis," Rheumatology, vol. 49, no. 8, pp. 1594-1597, 2010.

[15] G. Nesher, R. Nesher, M. Mates, M. Sonnenblick, and G. S. Breuer, "Giant cell arteritis: intensity of the initial systemic inflammatory response and the course of the disease," Clinical and Experimental Rheumatology, vol. 26, no. 3, pp. S30-S34, 2008.

[16] N. Mumoli, M. Cei, J. Vitale, and F. Dentali, “Tongue necrosis in giant-cell arteritis," QJM, vol. 108, no. 10, article 841, 2015.

[17] A. Lobato-Berezo, M. Alcalde-Villar, A. Imbernõn-Moya, M. Martínez-Pérez, A. Aguilar-Martínez, and P. Collado-Ramos, "Tongue necrosis: an unusual clinical presentation of giant cell arteritis," Arthritis and Rheumatology, vol. 66, no. 10, article 2803, 2014.

[18] R. Kumar, H. Gupta, A. Jadhav, and S. V. Khadilkar, "Bitemporal scalp, lip and tongue necrosis in giant cell arteritis: a rare presentation," Indian Journal of Dermatology, vol. 58, no. 4, p. 328, 2013.

[19] A. P. Kumarasinghe, A. Hepburn, W. J. Reuther, and C. Pratt, "Temporal arteritis presenting with tongue necrosis," BMJ Case Reports, vol. 2012, 2012.

[20] H. Husein-ElAhmed, J.-L. Callejas-Rubio, R. Rios-Fernández, and N. Ortego-Centeno, "Tongue infarction as first symptom of temporal arteritis," Rheumatology International, vol. 32, no. 3, pp. 799-800, 2012.

[21] S. Jennings and S. Singh, "Necrotic tongue: a rare manifestation of giant cell arteritis," Journal of Rheumatology, vol. 38, no. 12, article 2688, 2011.

[22] A. T. Zimmermann and M. Brown, "Tongue infarction in giant cell (temporal) arteritis," Internal Medicine Journal, vol. 38, no. 5, p. 376, 2008.

[23] A. Kusanale, H. Boardman, and H. Khoshnaw, "Tongue necrosis: a rare presentation of temporal arteritis," Age and Ageing, vol. 37, no. 1, article 119, 2008.

[24] K. H. Lethert and D. F. Jacobson, "Tongue necrosis from temporal arteritis," Journal of Hospital Medicine, vol. 2, no. 5, article 335, 2007.

[25] E. M. García, I. P. Tomás, E. O. Pastor, and A. J. F. Pérez, "Necrosis lingual como inicio de la arteritis temporal," Acta Otorrinolaringológica Española, vol. 54, no. 1, pp. 74-77, 2003. 


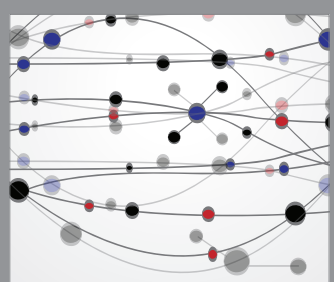

The Scientific World Journal
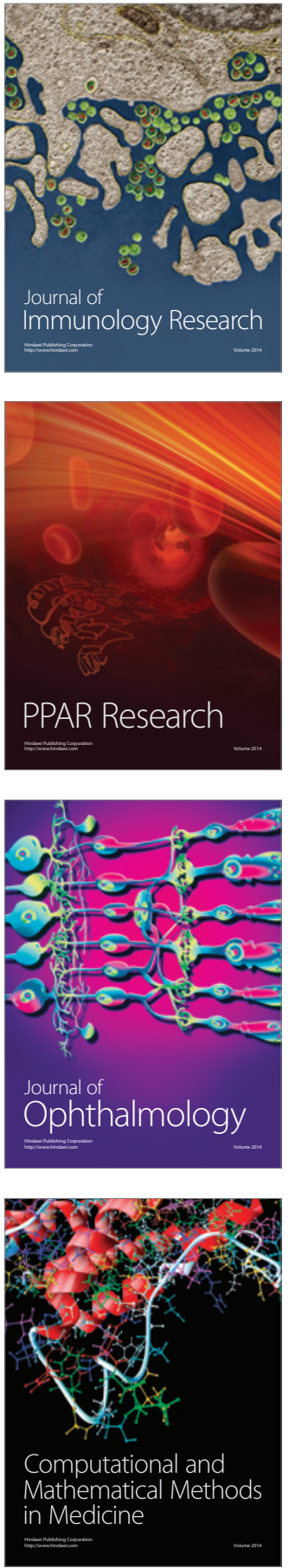

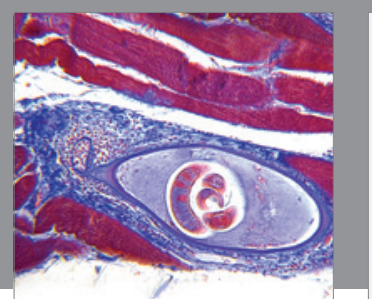

Gastroenterology Research and Practice
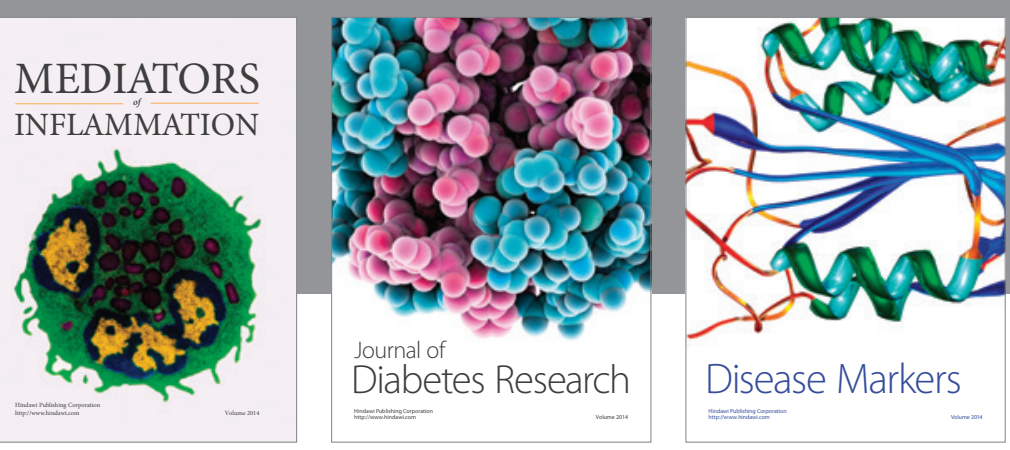

Disease Markers

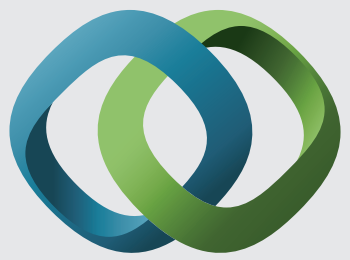

\section{Hindawi}

Submit your manuscripts at

https://www.hindawi.com
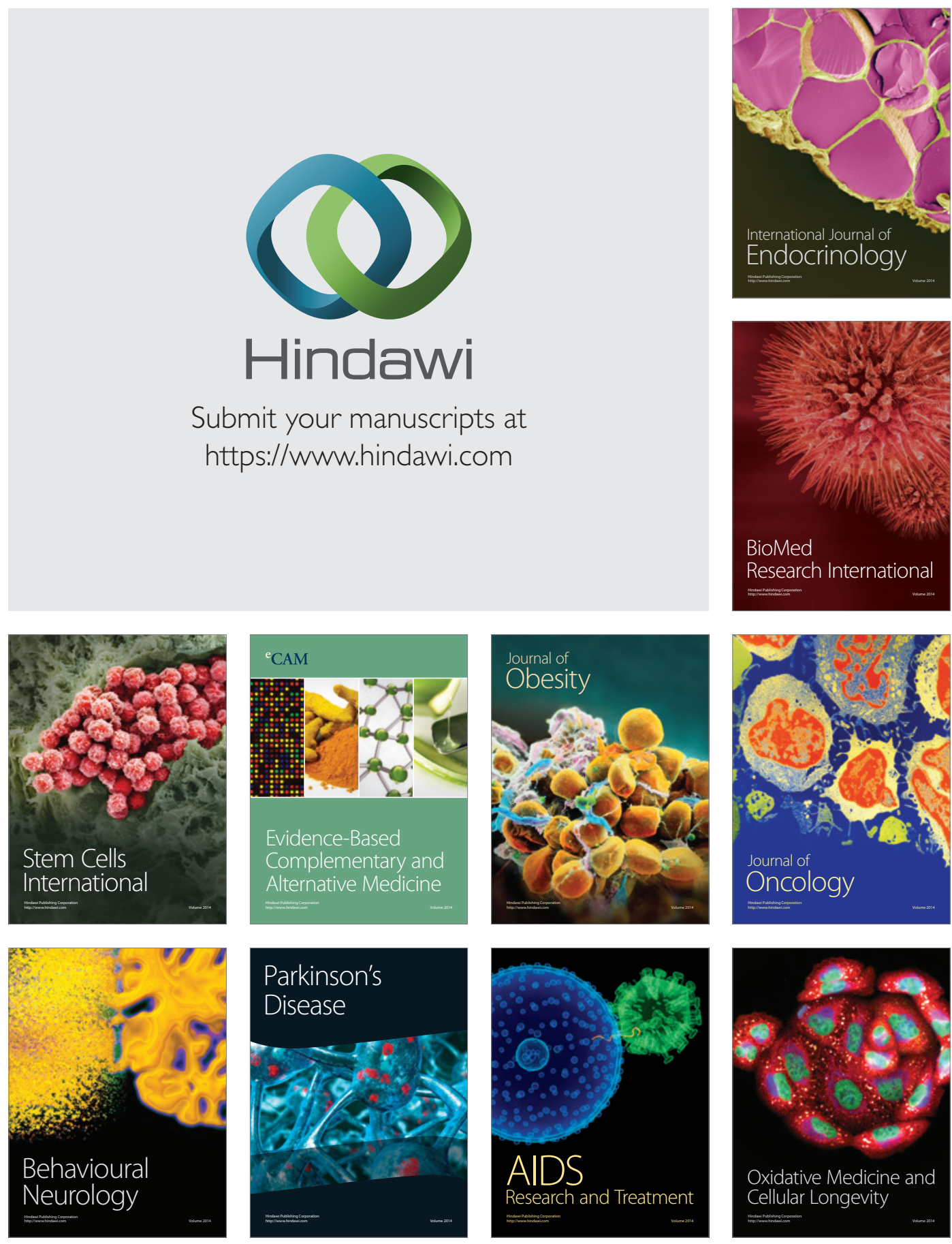